\title{
PENEMUAN HUKUM DALAM PUTUSAN MAHKAMAH AGUNG DAN RELEVANSINYA BAGI PENGEMBANGAN HUKUM ISLAM INDONESIA
}

\author{
Achmad Arief Budiman \\ IAIN Walisongo, Semarang \\ e-mail: budimanarief69@yahoo.co.id
}

\begin{abstract}
This qualitative research aimed to criticize the form of legal invention by the Supreme Court (MA) and its relevance to the development of Islamic law on Indonesia. This study also aims to find a model of the development of Islamic law through the dicovery made by the judge when adjudicating the case. The samples of this study were selected verdicts of MA based on the presence or absence of legal invention parameters in it The result of this study is that the two verdits of MA, precisely describe the form of the legal invention by showing courage and creativity at the same time in deciding the case. The legal invention of MA has significant contribution to the development of Islamic law in Indonesia. Because of the standing points of MA as the top judiciary, it's verdits would be as jurisprudence for the other judges, especially at the lower level court.
\end{abstract}

Penelitian kualitatif ini bertujuan untuk mengkritisi bentuk penemuan hukum oleh Mahkamah Agung (MA) dan relevansinya dengan pengembangan Hukum Islam Indonesia. Penelitian ini juga bertujuan untuk menemukan model pengembangan Hukum Islam Indonesia melalui terobosan yang dilakukan oleh hakim dalam mengadili suatu perkara. Sampel dalam penelitian ini adalah putusan MA yang diseleksi berdasar parameter ada tidaknya penemuan hukum di dalamnya. Hasil penelitian ini adalah bahwa dalam dua putusan kasasinya, MA telah melakukan penemuan hukum melalui keberanian serta kreativitasnya dalam memutus perkara. Penemuan hukum MA berkontribusi bagi pengembangan Hukum Islam Indonesia, dan karena dalam kedudukannya sebagai top judiciary, putusan MA akan menjadi yurisprudensi bagi hakim lain terutama di pengadilan tingkat di bawahnya.

Keywords: penemuan hukum, Hukum Islam, social justice, ijtihad

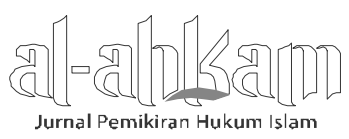




\section{Pendahuluan}

Ketua Muda Mahkamah Agung (TUADA) RI Urusan Lingkungan Peradilan Agama, Andi Syamsu Alam mengkritik lemahnya penegakan hukum di lingkungan Peradilan Agama. Hal itu disampaikan ketika ia membuka lokakarya "Kajian Hukum Acara Bagi Hakim Tinggi Mahkamah Syar'iyyah Provinsi Aceh dan Pengadilan Tinggi Agama se-Indonesia" di Bandung, Rabu 23 Juli 2008 lalu. Menurutnya, selama ini hakim Peradilan Agama dalam memutus suatu perkara terlalu terpaku pada pendekatan legal justice, dan kurang memperhatikan pendekatan social justice. ${ }^{1}$

Kritik TUADA MA RI tersebut berangkat dari realitas bahwa masih banyak hakim PA dalam mengadili suatu perkara terlalu terpaku pada teks hukum, sehingga hakim lebih mengedepankan asas normativitas hukum daripada kewajiban untuk menegakkan keadilan. Cara pandang yang membakukan teks hukum ini, menurut Satjipto Rahardjo, akan berimplikasi pada kegagalan dan memandulkan fungsi hukum itu sendiri. ${ }^{2}$ Karena dalam penegakan hukum, menurut Satjipto Rahardjo, hukum harus bisa direalisasikan untuk melayani manusia dalam menciptakan kehidupan yang lebih tertib dan bermaslahah.

Apabila dilacak lebih jauh, penyebab mandulnya hakim dalam menegakkan keadilan disebabkan oleh atmosfer penegakan hukum yang tidak sehat. Pertama, selama ini paradigma penegakan hukum lebih berorientasi pada kepastian hukum, bukan pada keadilan hukum. Ini menunjukkan bahwa hakim terjebak pada rangkaian prosedur dan mengabaikan substansi. Kedua, ada semacam 'ketakutan' di kalangan hakim PA untuk melakukan ijtihad hukum. Sebab, masih tertanam keyakinan bahwa ijtihad merupakan idiom keagamaan yang sulit dipenuhi kualifikasinya. Pada umumnya hakim PA lebih suka menghindari untuk berkonfrontasi dengan jalan menetapkan putusan yang tidak menyalahi UU atau fikih. ${ }^{3}$ Kenyataan di atas mengakibatkan Hukum Islam di Indonesia terkesan tidak berkembang, ekslusif, bahkan setback ke masa lalu. Hal ini dikarenakan masih banyak peraturan maupun putusan Hukum Islam, yang formulasinya masih terpaku pada aspek legal formal daripada spirit Hukum Islam yang mengutamakan kemaslahatan.

\footnotetext{
1 Lihat http://www.badilag.net/index.php situs resmi Badan Peradilan Agama Mahkamah Agung Republik Indonesia, data diunduh tanggal 5 Pebruari 2012.

${ }^{2}$ Satjipto Rahardjo, Sisi-sisi Lain dari Hukum di Indonesia (Jakarta: Kompas, 2006), h. 4, 16, 57, 11 , dan 92.

${ }^{3}$ Achmad Arief Budiman, "Ijtihad Hakim Pengadilan Agama Pasca Kompilasi Hukum Islam", Laporan Penelitian DIPA IAIN Walisongo, 2003.
}

2 || Volume 24, Nomor 1, April 2014

Jurnal Pemikiran Hukum Islam 
PA sendiri merupakan salah satu institusi penegak hukum yang memiliki peran strategis dalam penciptaan ketertiban hukum di Indonesia. Hal ini dikarenakan kompetensi PA berkaitan dengan eksistensi masyarakat Muslim yang secara kuantitatif sebagai mayoritas di negeri ini. Dengan demikian, apabila institusi PA dapat berfungsi secara optimal dalam penegakan hukum, dipastikan Hukum Islam akan ikut memberikan kontribusi dalam penegakan hukum dan keadilan di Indonesia.

Menjalankan tugasnya hakim diharapkan tidak menerapkan teks undangundang secara harfiah, namun hakim dituntut mewujudkan rasa keadilan dan kesejahteraan masyarakat. Untuk itu, UU dijadikan sebagai sarana untuk mencapai tujuan penegakan hukum. ${ }^{4}$ Di dalam penegakan hukum, seorang hakim memegang peran yang paling signifikan dalam proses itu. Bersama penegak hukum yang lain, yaitu polisi, jaksa, dan advokat, seorang hakim harus memahami hukum dan membuat keputusan dalam konteks yang tepat. Maka, agar penegak hukum dapat menjadi ujung tombak penegakan keadilan, maka khususnya bagi hakim harus bertindak sebagai a creative lawyer.

Satjipto Rahardjo menegaskan bahwa bagian terpenting dalam proses hukum adalah ketika hakim memeriksa dan mengadili suatu perkara. ${ }^{5}$ Karena hakim pada saat itu harus memeriksa kenyataan yang terjadi, serta menghukuminya dengan peraturan yang berlaku. Pada waktu diputuskan tentang bagaimana atau hukum apa yang berlaku untuk suatu kasus, maka dapat dikatakan pada waktu itu penegakan hukum mencapai puncaknya.

Tuntutan agar penegak hukum, khususnya hakim, bertindak secara progresif disebabkan tujuan yang dirumuskan dalam hukum seringkali begitu kabur, sehingga hakim harus menafsirkan dalam konteks yang ia hadapi. Bagi Doorn, tujuan yang hendak dicapai hukum seperti keadilan, kepastian, dan keserasian, masih terlalu umum sehingga hakim berpeluang mengembangkan penafsirannya sendiri mengenai tujuan hukum tersebut. ${ }^{6}$ Otoritas hakim untuk mengambil inisiatif yang berorientasi pada keadilan dalam penegakan hukum disebut dengan penemuan hukum.

\footnotetext{
${ }^{4}$ Qodri Azizy, "Menggagas Ilmu Hukum Indonesia", dalam Ahmad Gunawan dan Mu’ammar Ramadhan (ed.), Menggagas Hukum Progresif Indonesia (Semarang: Pustaka Pelajar-IAIN WalisongoPDIH UNDIP, 2006), h. ix.

${ }^{5}$ Satjipto Rahardjo, Ilmu Hukum (Bandung: Citra Aditya Bakti, 1996), h. 182-183.

${ }^{6}$ Satjipto Rahardjo, Hukum, Masyarakat dan Pembangunan (Bandung: Alumni, 1980), h. 74-76.

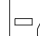

Jurnal Pemikiran Hukum Islam$$
\square
$$ 
Kewenangan melakukan penemuan hukum bersumber dari peraturan-peraturan untuk menempuh cara yang bijaksana dalam menjalankan tugasnya, dengan lebih mengutamakan idea moral daripada legal formal.7 Dengan demikian, dapat dikonklusikan bahwa pengertian penemuan hukum mencakup kewenangan yang bersifat bebas untuk mengambil keputusan yang sesuai dengan situasi yang dihadapi, tidak didasarkan pada lahiriah dari peraturan undang-undang yang berlaku tetapi atas dasar kebijaksanaan dan keadilan.

Esensi penemuan hukum terletak pada peran penegak hukum. Hakim tidak dituntut untuk menerapkan teks undang-undang secara harfiah, namun hakim dituntut pada terwujudnya rasa keadilan dan kesejahteraan masyarakat, dimana undang-undang dijadikan sebagai sarana untuk mencapai tujuan penegakan hukum. ${ }^{8}$ Jadi, pada dasarnya penemuan hukum merupakan kelengkapan dari sistem pengaturan hukum itu sendiri. ${ }^{9}$

Dalam bidang Hukum Islam, MA pernah melakukan penemuan hukum ketika memutus pemberian wāṣiyat wājibah sebagai pengganti hak waris bagi anak yang beragama Kristen. ${ }^{10}$ Putusan MA tersebut merupakan upaya menegakkan keadilan yang tidak bertentangan dengan teks Hadis yang tidak memperbolehkan ahli waris non-Muslim menerima hak waris. Contoh lain, putusan MA mengenai kasus perceraian Tamara Bleszyinski dengan Teuku Rafly Pasya dimana salah satu amar putusannya menetapkan pengasuhan anak keduanya Rassya Isslamay Pasya berada dalam pengasuhan ayahnya. ${ }^{11}$ Putusan MA ini telah memberikan corak hukum tersendiri dalam memberikan pertimbangan hukum pengasuhan anak yang berbeda dengan ketentuan Kompilasi Hukum Islam (KHI).

Keberanian hakim MA dalam memutus perkara tersebut dapat menjadi preseden dan yurisprudensi bagi hakim PA agar dalam mengadili suatu perkara secara tepat. Perubahan konteks waktu dan tempat merupakan faktor yang ber-

\footnotetext{
${ }^{7}$ Aaron merumuskan penemuan hukum sebagai, "...power authority conferred by law to action on the basic of judgement or conscience, and it use is more an idea of moral than law". Thomas Aaron, The Control of Police Discretions (Springfield: Charles D. Thomas, 1960), h. ix.

${ }^{8}$ Gunawan, Menggagas Hukum, h. ix.

9Fakam M., Penjaringan Perkara Pidana Polisi: Penemuan Hukum Kepolisian (Jakarta: Pradnya Paramita, 1991), h. 16.

10Putusan Kasasi Mahkamah Agung RI Nomor 368K/AG/1995.

11Putusan Kasasi Mahkamah Agung RI Nomor 349K/AG/2006 tanggal 3 Januari 2007.
}

4 Volume 24, Nomor 1, April 2014

Jurnal Pemikiran Hukum Islam 
pengaruh dalam penetapan hukum, sebagaimana dinyatakan dalam adagium fikih "taghayyur al-ahkkām bi taghayyur al-azmān wa '-amkān". Dalam konteks ini, maka pengembangan Hukum Islam Indonesia merupakan keniscayaan. Apalagi, selama ini substansi Hukum Islam yang terwakili oleh aturan-aturan mengenai perkawinan, waris, wakaf, zakat, dan lain-lain telah menunjukkan wujud pembaruan yang berwatak lokalitas keindonesiaan. Akomodasi nilai-nilai pembaruan dalam berbagai peraturan tersebut seharusnya juga diikuti oleh hakim PA untuk membangun Hukum Islam yang lebih konstruktif. Apabila hakim dapat menjalankan fungsinya sebagai penegak hukum dan bersinergi dengan pilar-pilar penegakan hukum yang lain, maka meminjam istilah Lawrence Friedman,, ${ }^{12}$ penegakan hukum akan dapat berjalan secara efektif.

Berdasar paparan di atas, dapat disimpulkan bahwa metode penemuan hukum merupakan salah satu alternatif mengatasi kemandulan hukum di Indonesia. Dalam hal ini Hukum Islam juga dapat berkontribusi menjadi instrumen penegakan hukum yang efektif sebagaimana dituntut oleh para pencari keadilan.

\section{Penemuan Hukum dalam Diskursus Hukum Islam dan Hukum Umum}

\section{Ijtihad dalam Hukum Islam}

Ijtihad Hukum Islam dapat diartikan sebagai perbuatan melalui proses tertentu dengan penuh kesungguhan yang dilakukan oleh mereka yang memiliki otoritas dalam penggalian Hukum Islam berdasarkan kaidah-kaidah istinbät yang dibenarkan. Menurut Muslehuddin, ijtihad adalah usaha yang dilakukan para mujtahid dalam menggali dan menetapkan Hukum Islam dari sumbernya (al-Qur'an dan al-Hadis). Apabila dihubungkan dengan peradilan, maka ijtihad diartikan sebagai jalan yang dilakukan hakim dalam memutuskan perkara, baik yang berkaitan dengan ketentuan UU atau dengan menyimpulkan dari hukum yang wajib diterapkan ketika tidak adanya nas (peraturan). ${ }^{13}$ Sebab, Islam sendiri menyadari bahwa dibandingkan dengan persoalan yang ketentuan hukumnya sudah ada, masih lebih banyak masalah lain yang belum diatur.

\footnotetext{
${ }^{12}$ Lawrence M. Friedman, American Law (New York: W.W. Norton \& Company, 1984), h. 5-6.

13Muhammad Muslehuddin, Filsafat Hukum Islam dan Pemikiran Orientalis: Studi Perbandingan Sistem Hukum Islam (Yogyakarta: Tiara Wacana, t.th.), h. 97, 130.

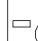

Jurnal Pemikiran Hukum Islam 
Ijtihad merupakan kata kunci memahami penemuan hukum. Dalam sejarah peradilan Islam banyak preseden mengenai penemuan hukum. Salah satunya adalah penemuan hukum yang dilakukan 'Umar ibn al-Khațtab. Dia dalam menerapkan hukum lebih mengedepankan ruh hukum yang terdapat al-Qur'an. Keberaniannya didasarkan pertimbangan bahwa al-Qur'an lebih berbicara pada nilai hukum yang berorientasi pada kemashlahatan, adapun teks adalah media untuk menyuarakan nilai itu. Karena legislasi al-Qur'an berada dalam kurun waktu tertentu, maka penerapannya perlu diselaraskan pada saat waktu yang berbeda. ${ }^{14}$ Misalnya 'Umar membebaskan seorang pencuri dari hukum potong tangan, karena pencuri itu terpaksa melakukan perbuatannya demi memberi makan keluarganya. Dalam menegakkan hukum, seorang hakim tidak dapat lepas dari ijtihad, terutama ijtihad tațbīqi, ${ }_{15}$ yakni usaha hakim untuk menerapkan hukum sesuai dengan perkara yang dihadapinya untuk menggali nilai keadilan yang masyarakat.

Berkaitan dengan penemuan hukum, terdapat adagium yang dijadikan legitimasi bahwa pemegang otoritas publik dapat menetapkan aturan sepanjang membawa kemaslahatan "tașarruf al-imām 'ala 'l-ra'ìyyah manūtun bi 'I-mașlaḥah". Dalam Hukum Islam, kemaslahatan merupakan substansi utama dari proses legislasi. Sebab, tujuan Shāri' menetapkan hukum untuk memelihara kemaslahatan, sekaligus untuk menghindari mafsadāt di dunia maupun di akhirat. ${ }^{16}$ Menurut al-Shāțibi, dalam rangka mewujudkan kemaslahatan, ada lima pokok hal yang harus dipelihara, yaitu agama, jiwa, akal, keturunan, dan harta. ${ }^{17}$

Ijtihad sebagai produk pemikiran Hukum Islam setidaknya dibagi menjadi 4, yaitu: 1) Fikih, sebagai hasil pemahaman, fikih sangat dipengaruhi oleh kondisi ruang dan waktu saat fuqah $\bar{a}^{\prime}$ memformulasikan pendapatnya sebagai respon atas kenyataan yang terjadi di lingkungannya. Noel J. Coulson menegaskan, ${ }^{18}$ salah satu karakter fikih adalah beragam (diversity) dan mengalami perubahan sesuai tantangan ruang dan waktu. 2) Fatwa, adalah hasil ijtihad mufti dalam masalah

\footnotetext{
14Fazlur Rahman, Islam and Modernity, terj. Ahsin Mohammad, Islam dan Modernitas: tentang Transformasi Intelektual (Bandung: Pustaka, 1995), h. 16.

${ }^{15}$ Muhammad Salam Madzkur, al-Qaḍa' bi '-Islām, terj. Imron A.M., Peradilan dalam Islam (Surabaya: Bina Ilmu, 1990), h. 130.

16Fathurrahman Djamil, Filsafat Hukum Islam (Jakarta: Logos Wacana Ilmu, 1997), h. 125.

17al-Shātibī, al-Muwāfaqāt fi Ușūl al-Ahkām, Jilid III (Beirut: Dār al-Fikr, t.th.), h. 62-64 dan 70.

${ }^{18}$ Noel J. Coulson, Conflict and Tension in Islamic Jurisprudence (Chicago: The University of Chicago Press, 1969), h. 3-16.
} 
hukum yang diajukan kepadanya. ${ }^{19}$ Fatwa memuat Hukum Islam yang berhubungan dengan berbagai persoalan, baik ibadah, muamalah, dan sebagainya. Fatwa lebih spesifik dari ijtihad. Spesifikasi kasus pada fatwa bisa jadi karena keputusan hukum yang difatwakan sudah ada ketentuannya dalam fikih, tetapi belum dipahami oleh peminta fatwa. ${ }^{20} 3$ ) Putusan Pengadilan, adalah produk pemikiran Hukum Islam yang dilakukan hakim berdasarkan pemeriksaan di depan persidangan. ${ }^{21}$ Secara teknis, putusan pengadilan disebut al-qad̄ $\bar{a}^{\prime}$ atau $a l-h u k m$, yaitu penetapan atau keputusan yang dibuat lembaga yang berwenang menjalankan kekuasaan itu (al-wilāyah al-qad̄ōj).22 4) Peraturan perundang-undangan, yaitu peraturan yang dibuat badan legislatif yang mengikat setiap warga negara di wilayah perundangundangan itu diterapkan.

\section{Penemuan Hukum}

Penemuan hukum diartikan proses pembentukan hukum oleh hakim atau petugas hukum lain yang diberi tugas melaksanakan hukum terhadap peristiwa hukum yang konkret. Ini merupakan konkretisasi peraturan hukum yang bersifat umum dengan mengingat peristiwa konkret. ${ }^{23}$ Substansi UU pada dasarnya tidak lengkap atau tidak jelas, maka hakim harus mencari dan menemukan hukumnya (rechtsvinding). Penegakan dan pelaksanaan hukum sering merupakan penemuan hukum dan tidak sekedar penerapan hukum.

Istilah penemuan hukum seringkali disalah-kelirukan dengan istilah pelaksanaan hukum, penerapan hukum, pembentukan hukum, atau penciptaan hukum. Berbeda dengan istilah-istilah tersebut, menurut Soedikno Mertokusumo, penemuan hukum adalah proses pembentukan oleh hakim, atau aparat hukum lainnya yang ditugaskan untuk penerapan peraturan hukum umum pada peristiwa hukum konkret. Penemuan hukum adalah proses konkretisasi atau individualisasi peraturan hukum (das sollen) yang bersifat umum dengan mengingat akan peristiwa konkret (das sein) tertentu. ${ }^{24}$

\footnotetext{
${ }^{19}$ Ahmad Rofiq, Hukum Islam di Indonesia (Jakarta: Rajawali Press, 1995), h. 8.

${ }^{20}$ Muhammad Abū Zahrah, Ușūl al-Fiqh (Mesir: Dār al-Fikr al-'Arabī, t.th.), h. 401.

21 Ibid., h. 8.

22 Madhkūr, al-Qaḍā', h. 20.

23Sudikno, Mengenal Hukum (Yogyakarta: Liberty, 1999), h. 147.

24 Ibid., h. 37.
}

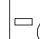

Jurnal Pemikiran Hukum Islam 
Adapun metode-metode penemuan hukum meliputi: metode interpretasi gramatikal, interprestasi historis, interpretasi sistematis, ${ }^{25}$ interpretasi sosiologis atau teleologis, intepretasi otentik atau resmi, interpretasi ekstentif, interpretasi restriktif, interpretasi analogi (argumentum per analogiam), argumentum a contrario, penyempitan hukum (rechtsverfijning), argumentasi, eksposisi, penemuan hukum bebas, interpretasi komparatif, ${ }^{26}$ interpretasi futuristik, sinonimisasi, terjemahan, antitese, ampliasi, paraleli, deskripsi, enumerasi, archetipasi, ilustrasi, dan eksemplifikasi. ${ }^{27}$

\section{Penemuan Hukum dalam Putusan Mahkamah Agung}

\section{Putusan Mahkamah Agung RI No. 349K/AG/2006}

Tugas untuk memelihara anak (haḍānah) merupakan tanggung-jawab kedua orang tua. Tanggung-jawab tersebut melekat bukan saja ketika perkawinan masih berlangsung, tetapi juga pada saat suami dan isteri sudah bercerai. Dalam hal perkawinan masih berlangsung, kedua orang tua secara bersama-sama dapat menjalankan kewajiban tersebut. Namun apabila keduanya bercerai, maka pemeliharaan anak dapat menimbulkan permasalahan. Problem tersebut dapat berupa tidak terlaksananya pemeliharaan anak, bahkan terjadi persengketaan hak pemeliharaan antara suami isteri atas anak mereka.

\section{Analisis terhadap Putusan Pengasuhan Anak}

Masalah pengasuhan anak (haḍānah) kembali menjadi tema diskusi yang menarik, terutama setelah adanya putusan MA No. 349K/AG/2006 tanggal 3 Januari 2007 mengenai kasus perceraian antara Tamara Blezynski dengan Teuku Rafly Pasya yang salah satu objek sengketanya adalah mengenai hak pengasuhan anak keduanya bernama Rassya Islamay Pasya. Persoalan di atas menyedot perhatian publik, bukan hanya karena menyangkut perceraian artis, tetapi yang menarik MA memutus perkara itu secara tidak biasa. Diskusi-diskusi bermunculan, terutama yang mempersoalkan landasan yuridis putusan MA yang terkesan bertentangan dengan ketentuan pengasuhan anak dalam $\mathrm{KHI}$.

\footnotetext{
25 Ibid., h. 156 dan 57.

${ }^{26} \mathrm{Ibid}$, h. 62, 69-70. Lihat juga Sudikno, Mengenal Hukum, h. 159, 160-169.

27 Ibid., h. 71-72.
}

8 || Volume 24, Nomor 1, April 2014 
Mengkaji persoalan pengasuhan anak tidak bisa dilepaskan dari aturan yang menjadi dasar pelaksanaannya. KHI Pasal 105 menyatakan dalam hal terjadinya perceraian:

(1) Pemeliharaan anak yang belum mumayyiz atau belum berumur 12 tahun adalah hak ibunya;

(2) Pemeliharaan anak yang sudah mumayyiz diserahkan kepada anak untuk memilih di antara ayah atau ibunya sebagai pemegang hak pemeliharaannya;

(3) Biaya pemeliharaan ditanggung oleh ayahnya.

Ketentuan di atas, secara implisit menunjukkan bahwa KHI dan UU No. 3 Tahun 2006 masih bersifat global, sehingga belum memberi solusi secara definitif persoalan yuridis pengasuhan anak pada saat kedua orang tuanya bercerai. Kecuali ketentuan KHI Pasal 105, KHI Pasal 156 menyatakan bahwa akibat putusnya perkawinan karena perceraian: 1) Anak yang belum mumayyiz berhak mendapatkan hạ̣ānah dari ibunya, kecuali apabila ibunya telah meninggal dunia, maka kedudukannya digantikan oleh: a) wanita-wanita dalam garis lurus ke atas dari ibu; b) ayah; c) wanita-wanita dalam garis lurus ke atas dari ayah; d) saudara perempuan dari anak yang bersangkutan, dan e) wanita-wanita kerabat sedarah menurut garis samping dari ayah; 2) Anak yang mumayyiz berhak memilih mendapatkan hậ̣̄nah dari ayah atau ibunya; 3) Apabila pemegang hạ̣ānah ternyata tidak dapat menjamin keselamatan jasmani dan rohani anak, meskipun biaya nafkah dan haḍ̄̄nah telah dicukupi, maka atas permintaann kerabat yang bersangkutan Pengadilan Agama dapat memindahkan hak haḍānah kepada kerabat lain yang mempunyai hak ḥaḍ̄nah pula;

Dari uraian di atas dapat disimpulkan bahwa KHI Pasal 105 menentukan pengasuhan anak pada dua keadaan: Pertama, anak belum mumayyiz (belum berumur 12 tahun) pengasuhan anak tersebut ada pada ibunya. Kedua, anak sudah mumayyiz (umur 12 tahun ke atas) diserahkan kepada anak untuk memilih antara ayah atau ibunya untuk mengasuhnya. Sedangkan KHI Pasal 156 mengatur pengasuhan anak saat ibu kandungnya meninggal, dengan menetapkan hak pengasuhan kepada pihak keluarga secara berurutan. Di samping itu Pasal 156 huruf c menyatakan hak pengasuhan anak dapat gugur apabila pemegang haḍ̄nah tidak dapat menjamin keselamatan jasmani dan rohani anak, yang selanjutnya PA dapat mengalihkan hak haḍ̄anah kepada kerabat lain yang memiliki hak haḍanah. UU No. 3 Tahun 2006 tidak memberi pengaturan berarti mengenai pengasuhan anak. 
Dalam putusan MA yang menyidangkan kasus perceraian Tamara Bleszyinski dengan Teuku Rafly Pasya, salah satu amar putusannya menetapkan anak berada dalam pengasuhan ayahnya, padahal anak tersebut masih di bawah 12 tahun. MA pada putusan lain menetapkan pengasuhan anak ke ayahnya karena isteri murtad ke agama semula. Dari putusan MA No. 210K/AG/1996 dapat dikonklusikan bahwa masalah agama menjadi syarat mutlak dalam menentukan hak pengasuhan bagi ibu atas anak yang belum mumayyiz. ${ }^{28}$ Menurut Syamsuhadi Irsyad, putusan MA tentang pengasuhan anak yang menetapkan kepada ayah didasarkan pertimbangan pada keselamatan aqidah anak. ${ }^{29}$

Apabila memperhatikan putusan MA nampak adanya orientasi yang kuat dari putusan itu dengan mendasarkan pada maqāṣid al-shar'iyyah, bahwa penjagaan aqidah merupakan syarat untuk menentukan gugur tidaknya hak seorang ibu atas pengasuhan anaknya yang belum mumayyiz. Persoalan aqidah menjadi parameter diperolehnya hak haḍanah atas anak. Putusan MA tersebut telah menampakkan keberanian dan kreativitas hakim dalam mengkonstruksi hukum pengasuhan anak yang berbeda dengan aturan normatif.

Dalam kasus pengasuhan anak oleh seorang ibu murtad sebagaimana dalam putusan MA No. 210K/AG/1996 di atas, mudah dipahami mengapa MA mengalihkan tanggung-jawab pengasuhan kepada ayah. Namun dalam putusan MA No. 349K/AG/2006 keadaan Tamara sebagai ibu dari Rassya Islamay Pasya statusnya beragama Islam. Hanya saja keadaan Tamara adalah seorang muallaf. Karena itu putusan MA dalam kasus perceraian Tamara dengan suaminya yang berimplikasi pada pengasuhan anak perlu ditelaah mengenai dasar pertimbangan hukum dari pengalihan hak asuh ibu.

Pertimbangan aqidah orang tua sebagai dasar kelayakan mengasuh anak merupakan pertimbangan dari sudut syar'i yang mengedepankan maqāṣid alshar'iyyah yaitu menjaga agama Islam. Dalam hal ini, menurut Satria Effendi hadạnah dibagi dua pengaturan:30 1) Periode belum mumayyiz. Demi kepentingan

\footnotetext{
28Sugiri Permana, Paradigma Baru dalam Penyelesaian Sengketa Hak Asuh Anak Pada Peradilan Agama dalam http://badilag.mahkamahagung.go.id/ artikel/1302.html data diunduh pada Minggu, 9 Juni 2013.

${ }^{29}$ Syamsuhadi Irsyad, Kapita Selekta Hukum Perdata Agama Pada Tingkat Kasasi, dalam Achmad Djunaeni, Putusan Pengadilan Agama dalam Yurisprudensi MA, MA RI, 2004, h. 20 dan 149.

${ }^{30}$ Satria Effendi M. Zein, Problematika Hukum Keluarga Islam Kontemporer: Analisis Yurisprudensi dengan Pendekatan Ushuliyah (Jakarta: UIN Jakarta dan Balitbang Depag RI, 2005), h. 170-171.
} 
anak yang belum mumayyiz (setelah lahir hingga tujuh atau delapan tahun), ibu lebih berhak untuk mengasuhnya, bilamana terpenuhi persyaratan-persyaratan bagi pengasuhan anak. Dalam hal ini, Ibn Qudāmah menyatakan tidak ada perbedaan pendapat di kalangan ulama mengenai masalah tersebut. 2) Periode mumayyiz. Anak yang mumayyiz diberi hak pilih untuk menentukan apakah ia ikut ibu atau ayahnya.

Lebih lanjut Guru Besar UIN Jakarta tersebut juga menentukan syarat-syarat bagi orang tua yang akan melakukan haḍānah, yaitu: 1) baligh dan tidak terganggu akalnya, sebab haḍānah merupakan pekerjaan yang penuh tanggung-jawab, 2) mempunyai kemampuan memelihara dan mendidik mahdūun (anak yang diasuh), 3) dapat dipercaya memegang amanah, sehingga orang yang rusak akhlaqnya tidak layak melakukan tugas ini, 4) jika yang mengasuh adalah ibunya, maka disyaratkan tidak kawin dengan lelaki lain. Dasarnya, Hadis yang diriwayatkan Abū Dāwud bahwa "seorang ibu hanya mempunyai hak haḍannah bagi anaknya selama ia belum menikah dengan lelaki lain", 5) beragama Islam, karena itu apabila orang tua tidak beragama Islam, maka ia dapat kehilangan hak asuhnya.

Pernyataan di atas dipertegas Amir Syarifuddin yang menyatakan ibu dan ayah yang akan memelihara anak mereka dipersyaratkan harus beragama Islam. Persyaratan ini dianut jumhur ulama, karena tugas pengasuhan itu termasuk tugas pendidikan yang akan mengarahkan agama anak yang diasuh. Kalau anak tersebut diasuh oleh orang yang bukan beragama Islam, maka dikhawatirkan anak yang diasuh akan jauh dari agamanya. ${ }^{31}$

Pernyataan Satria Effendi seperti tertera di atas kalau dipahami secara mafhüm mukhālafah, berarti bagi seorang ibu yang berpisah dengan suaminya namun tidak memenuhi persyaratan, maka ibu tersebut tidak berhak untuk mengasuh anaknya meski anak itu belum mumayyiz. Apabila dihubungkan dengan ketentuan dalam KHI, terdapat relevansi karena pengaturan pengasuhan anak dalam KHI juga menentukan dipenuhinya syarat sebagaimana ditegaskan dalam Pasal 156 KHI: "apabila pemegang haḍānah ternyata tidak dapat menjamin keselamatan jasmani dan rohani anak, maka atas permintaan kerabat yang bersangkutan PA dapat memindahkan hak haḍānah kepada kerabat lain yang mempunyai hak hadāanah pula." Ketentuan dalam Pasal 156 KHI tersebut merupakan kriteria

${ }^{31}$ Amir Syarifuddin, Hukum Perkawinan Islam di Indonesia: Antara Fikih Munakahat dan UndangUndang Perkawinan (Jakarta: Prenada Media, 2006) h. 326.

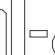

Jurnal Pemikiran Hukum Islam 
penting dan menentukan apakah orang tua dapat mengasuh atau kehilangan hak dalam pengasuhan anak.

Hal itu juga menegaskan bahwa dalam penentuan pengasuhan anak, hakim Peradilan Agama berpegang pada maqāșid al-sharizyyah sebagaimana dirumuskan oleh al-Shāțibi.32 Dalam konsep maqāșid al-shar'iyyah tersebut, secara hierarkis disebutkan ada lima tujuan utama yang ingin dicapai dalam aturan Islam; hifz al-dinn, hifž an-nafs, hifž al-'aql, hifž al-'ird, dan hifź al-māl. ${ }^{33}$ Ketentuan maqāṣid al-shar'ïyyah tersebut merupakan hierarki yang urutan atau pertingkatannya harus sesuai dan tidak boleh di balik-balik. Sebaliknya, urutan yang berada di bawah bisa dikalahkan demi tujuan yang lebih tinggi, misalnya, diperbolehkan mengorbankan harta benda untuk kepentingan menjaga agama. Dalam konteks perceraian Tamara Blezynski dengan Teuku Rafly Pasya, dimana putusan MA memberi hak pengasuhan Rassya Islamay Pasya kepada Teuku Rafly Pasya, maka dapat disimpulkan bahwa pertimbangan utama para hakim MA dalam memutus pemberian hak haḍ̄nah itu adalah kemaslahatan agama anak yang masih belum mumayyiz.

Sebagai komparasi Pasal 49 UU No. 1 Tahun 1974 menerangkan kemungkinan orang tua atau salah satu dari keduanya dapat dicabut kewenangannya dalam pengasuhan anak untuk waktu tertentu. Kewenangan orang tua dapat dicabut, karena mereka melalaikan kewajiban, atau memiliki kelakuan yang buruk. Ketentuan Pasal 49 UU No. 1 Tahun 1974 menunjukkan bahwa penetapan pengasuhan anak oleh salah satu orang tuanya bukan merupakan penetapan yang permanen, namun hak pengasuhan anak sewaktu-waktu dapat dialihkan pada pihak lain melalui gugatan pencabutan kekuasaan yang diajukan ke Pengadilan. ${ }^{34}$

\section{Hakim dan Penyimpangan Peraturan Normatif}

Kajian tentang penegakan hukum sering bersentuhan dengan dilema antara kepastian hukum dan keadilan hukum. Di sini, hakim dihadapkan pada pilihan untuk melihat kedudukan hukum dari peraturan normatif yang ada dan sistem hukum yang berlaku. Keadilan dan kepastian hukum merupakan dua faktor yang saling mendukung dalam menjaga tatanan masyarakat. Kepastian hukum ter-

\footnotetext{
32al-Shātibi, al-Muwāfaqat, h. 5.

${ }^{33}$ Rincian dari kelima prinsip maqāṣid al-sharı̄ah dibahas dengan detail oleh Fathurrahman Jamil, Filsafat Hukum Islam (Jakarta: Logos, 1997), h. 128-131.

${ }^{34}$ Sugiri Permana, "Paradigma Baru dalam Penyelesaian Sengketa Hak Asuh Anak pada Peradilan Agama” diunduh dari www.badilag.net/data/ARTIKEL/varia.pdf, Jum'at, 13 September 2013.
} 
cermin dalam peraturan ataupun kaidah-kaidah umum, sementara keadilan bersifat khusus karena berupa penghargaan bagi individu dalam masyarakat. ${ }^{35}$ Pada sisi lain mazhab hukum Indonesia merupakan perpaduan dari sistem hukum Anglo Saxon dan Eropa Continental. Pasal 25 (1) UU No. 4 Tahun 2004 tentang Kekuasaan Kehakiman menyatakan segala putusan pengadilan selain harus memuat alasan dan dasar putusan, memuat pula pasal tertentu dari peraturan perundang-undangan yang bersangkutan atau sumber hukum tak tertulis yang dijadikan dasar untuk mengadili.

Keharusan memuat peraturan perundang-undangan memperlihatkan bahwa UU merupakan sumber hukum utama seperti mazhab hukum Eropa Continental. Sedangkan keharusan memuat sumber hukum tak tertulis merupakan satu corak Anglo Saxon sebagaiman ditegaskan Pasal 28 UU No. 4 Tahun 2004 yang mewajibkan hakim untuk menggali, mengikuti dan memahami nilai hukum dan rasa keadilan yang hidup dalam masyarakat. Dengan demikian sistem hukum di Indonesia merupakan perpaduan dua mazhab hukum. Seandainya hakim menghadapi perbedaan antara peraturan perundang-undangan dengan nilai-nilai keadilan yang hidup di masyarakat maupun yurisprudensi, maka harus dipahami bahwa dalam kaidah sistem common law, apabila terjadi konflik antara common law dan statute law, serta antara yurisprudensi dengan perundang-undangan, maka UU akan mengalahkan yurisprudensi. ${ }^{36}$ Putusan hakim dimungkinkan dapat berbeda dengan peraturan, yang dikenal dengan contra legem. Penyimpangan tersebut dilakukan apabila terdapat alasan hukum yang kuat dengan mempertimbangkan berbagai aspek hukum. ${ }^{37}$ Perspektif di atas dapat membantu penelaahan terhadap masalah penyimpangan terhadap ketentuan normatif dalam penyelesaian perkara persengketaan pengasuhan anak.

Dalam hal ini, metode penafsiran restriktif (pembatasan makna), ${ }^{38}$ atau metode penalaran rechtsvervijning (penyempitan makna) dapat digunakan memahami masalah ini. Penafsiran restriktif dilakukan dengan mempersempit arti

\footnotetext{
35Soerjono Soekamto, Kegunaan Sosiologi Hukum Bagi Kalangan Hukum (Bandung: Citra Aditya Bakti, 1991), h. 50-51.

${ }^{36}$ Ahmad Kamil, Kaidah-kaidah Hukum Yurisprudensi (Jakarta: Prenada Media, 2005), h. 40.

${ }^{37}$ Ibid, , h. 9.

${ }^{38}$ Contoh penafsiran restriktif (pembatasan makna) seperti dalam kata kerugian yang ditafsirkan tidak termasuk kerugian yang tidak berwujud (imateriil). Diadaptasi dari http://www.jurnalhukum. com/penafsiran-hukum-interpretasi-hukum/ diunduh pada hari Rabu, 22 Mei 2013.
}

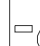

Jurnal Pemikiran Hukum Islam 
kata-kata yang terdapat dalam peraturan. Dengan metode ini, maka pembatasan usia 12 tahun dalam KHI sebagai batas akhir usia tidak mumayyiz. Dengan bahasa yang berbeda setelah usia 12 tahun, seorang anak dikatakan mumayyiz. Sebaliknya bagi anak yang berusia kurang dari 12 tahun, hakim dapat menentukan apakah anak itu sudah mumayyiz atau belum. 39

Penjelasan di atas menunjukkan bahwa penentuan mumayyiz bagi seorang anak dalam KHI dengan batas usia 12 tahun merupakan hasil ijtihad, karena tidak adanya ketentuan yang pasti dalam penentuan batas umur pengasuhan. Hal itu berarti bahwa penentuan umur 12 tahun bukan patokan mutlak. Hakim yang mengadili sengketa pengasuhan anak di bawah umur 12 tahun, dapat mempertimbangkan anak apakah sudah mumayyiz atau belum. Pertimbangan tersebut dapat dijadikan dasar bagi hakim dalam menentukan hak kepada anak untuk memilih pengasuhan pada bapak atau ibunya.

Untuk mengkaji masalah ini penting menkonfirmasikan dengan pemikiran mazhab hukum Anglo Saxon yang menyatakan bahwa hukum dikatakan baik apabila hukum itu memiliki relevansi dengan hukum yang hidup di tengah masyarakat.40 Menurut teori hukum, konstruksi hukum seperti itu merupakan pendekatan hermeneutika, yang memberi kesempatan kepada ahli, praktisi hukum termasuk hakim supaya tidak terjebak oleh kepentingan profesi. Strategi metodologis pendekatan ini menganjurkan hakim untuk selalu to learn from people, mengajak para ahli dan praktisi hukum hakim agar bersedia menggali dan melakukan penelitian atas makna hukum dari perspektif para pencari keadilan. ${ }^{41}$

Implementasi prinsip to learn from people tergambar dalam putusan MA No. 349K/AG/2006 mengenai perceraian antara Tamara Bleszyinski dengan Teuku Rafly Pasya. Pada satu sisi putusan MA tersebut memperlihatkan sikap yang berbeda dengan $\mathrm{KHI}$, namun pada sisi lain, hakim MA juga menempatkan penyelesaian pengasuhan anak secara ex officio untuk ikut mencari solusi penyelesaian sengketa pengasuhan anak dalam perceraian. Ini adalah bentuk konstruksi hukum yang dilakukan dengan menafsirkan ketentuan yang ada.

\footnotetext{
39 Sugiri Permana, "Paradigma Baru dalam Penyelesaian Sengketa Hak Asuh Anak pada Peradilan Agama”. Diunduh dari http://badilag.mahkamahagung.go.id/artikel/1302.html pada Minggu, 9 Juni 2013.

40Lili Rasjidi dan Ira Rasjidi, Dasar-dasar Filsafat dan Teori Hukum (Bandung: Alumni, 2001), h. 66.

${ }^{41}$ Otje Salman, Anton F. Susanto, Teori Hukum, Mengingat, Mengumpulkan dan Membuka Kembali (Bandung: Refika Aditama, 2005), h. 82.
}

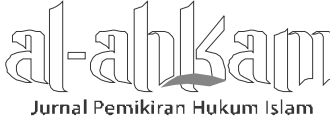




\section{Perbandingan Putusan}

Apabila melihat ketentuan KHI Pasal 156 a dan c dan putusan hakim MA yang memutuskan pemegang hak pengasuhan (haḍānah) anak, terlihat hakim MA dalam putusan No. 210K/AG1996/MA melakukan penemuan hukum dengan penafsiran argumentum a contrario. Penafsiran argumentum a contrario adalah suatu penafsiran yang memberi perlawanan pengertian antara peristiwa konkrit yang dihadapi dengan peristiwa yang diatur UU. Berdasarkan perlawanan ini disimpulkan bahwa perkara yang dihadapi tidak termasuk dalam pasal tersebut melainkan di luar peraturan perundang-undangan. ${ }^{42}$

Menurut Scolten pada hakikatnya tidak ada perbedaan antara menjalankan UU secara analogi dan mengimplementasikan UU secara argumentum a contrario. Hanya saja terdapat perbedaan hasil dari kedua hal tersebut: 1) pada analogi keputusan hakim akan membawa hasil yang positif, 2) sedangkan secara argumentum a contrario membawa hasil negatif. ${ }^{43}$ Dalam putusan tersebut hakim MA melihat alasan berbeda dalam KHI Pasal 156 a dan c, sehingga hak pengasuhan yang sebelumnya berada di tangan ibu dialihkan kepada bapaknya.

Berbeda dengan putusan perkara kasasi MA No. 210K/AG/1996, maka putusan hakim MA dalam kasus Tamara Blezynski versus Teuku Rafly Pasya yang menetapkan mengenai hak haḍ̄nah Rassya Islamay Pasya berada pada kekuasaan Teuku Rafly Pasya, perlu penelaahan yang lebih cermat. Ada kesan bahwa putusan MA kasus Tamara menggunakan penemuan hukum argumentum a contrario, karena putusan pengalihan hak haḍānah anak yang belum berumur 12 tahun semestinya merupakan hak ibu beralih pada kerabat lain (termasuk bapak) apabila hakim mempertimbangkan ibu tidak memenuhi syarat pengasuhan. KHI Pasal 156 huruf c menyatakan: "Apabila pemegang haḍ̄nah ternyata tidak dapat menjamin keselamatan jasmani dan rohani anak, meskipun biaya nafkah dan hậānah telah dicukupi, maka atas permintaan kerabat yang bersangkutan PA dapat memindahkan hak haḍ̂̄nah kepada kerabat lain yang mempunyai hak hạ̣anah pula."

Secara lebih spesifik kemungkinan alasan yang dimaksudkan hakim apabila merujuk pada redaksi "tidak dapat menjamin keselamatan jasmani dan rohani anak," salah satu yang dimaksud bisa jadi terkait dengan aspek keagamaan ibu yang ber-

42Liza Erwina, "Penemuan Hukum oleh Hakim (Rechtvinding)”, Fakultas Hukum Jurusan Hukum Pidana USU, diadaptasi dari www.slideshare.net diunduh pada Jum'at, 13 September 2013.

43 Ibid.

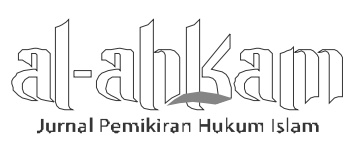


beda dengan anak, sehingga hal ini dapat membahayakan kemaslahatan rohani anak apabila anak itu berada dalam pengasuhannya. Namun apabila putusan hakim MA disimak lebih lanjut, alasan dalam KHI Pasal 156 huruf c di atas sebenarnya tidak terdapat dalam kasus tersebut, karena ibu dalam hal ini Tamara tidak berbeda agama dengan anak, melainkan Tamara masih sebagai seorang mu'allaf. Dengan demikian hakim MA dalam memutuskan kasus di atas bisa dipahami telah mendasarkan pada pertimbangan lain berdasarkan pengetahuan hakim (qaīinah).

Sebagaimana dinyatakan Hasbi Hasan, Kabag Sespim Biro Kesekretariatan Pimpinan MA, ${ }^{44}$ bahwa hakim MA mengkhawatirkan kondisi Tamara yang berstatus mu'allaf akan berbalik pada agamanya semula (Kristen) setelah bercerai dengan suaminya. Karena itu, MA bersikap hati-hati dalam menghadapi masalah ini, sehingga MA memutuskan suatu putusan yang berbeda dengan redaksi aturan yang ada di dalam KHI. ${ }^{45}$ Ketentuan KHI Pasal 156 sebagaimana telah diuraikan di atas menegaskan apabila suami isteri bercerai, anak yang masih berusia 12 tahun berada dalam pengasuhan ibunya. Meskipun Rassya masih belum mumayyiz yang mestinya berada dalam pengasuhan ibunya, namun MA memutuskan Rassya berada dalam pengasuhan bapaknya.

Dari pernyataan Hasbi Hasan di atas dapat disimpulkan bahwa dalam putusan kasasi MA tersebut apabila dikaji dari perspektif metodologi Hukum Islam terlihat bahwa MA menerapkan kaidah sadd al-dharīah. Kaidah ini bersifat preventif yang mempertimbangkan adanya dua akibat berupa kebaikan dan keburukan dalam satu masalah. Putusan MA di atas merupakan bentuk pencegahan dan antisipasi hakim atas satu keadaan apabila ketentuan hukum positif (KHI) diterapkan.

\section{Analisis Putusan Pemberian Harta Peninggalan pada Ahli Waris Berbeda Agama Putusan MA No. 368 K/AG/1995 tanggal 16 Juli 1998}

Hukum kewarisan Islam yang diterapkan di masyarakat Muslim Indonesia pada dasarnya sudah diatur dalam kitab-kitab fikih ilmu waris (farāiḍ). Tetapi, sepanjang sejarah peradilan di Indonesia hukum kewarisan Islam baru terkodifikasikan setelah ditetapkan oleh Inpres No. 1 Tahun 1991 yang menginstruk-

\footnotetext{
${ }^{44}$ Sebagaimana disampaikan oleh Hasbi Hasan dalam Seminar Nasional yang diselenggarakan oleh Fakultas Syari'ah dalam rangka Dies Natalis IAIN Walisongo ke-41 yang bertema "Yurisprudensi Mahkamah Agung dan Prospeknya dalam Pengembangan Hukum Perdata Islam Indonesia”, pada hari Selasa, 5 April 2011.

45 Ibid.

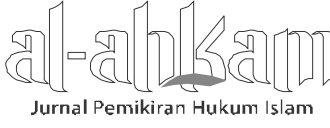


sikan penyebarluasan KHI untuk dipergunakan sebagai pedoman dalam menyelesaikan masalah di bidang perkawinan, kewarisan, dan perwakafan baik oleh instansi pemerintah maupun masyarakat.

Eksistensi KHI diharapkan menjadi pedoman yang unifikatif bagi hakim lembaga PA dan menjadi hukum positif yang dipatuhi umat Islam Indonesia. ${ }^{46}$ Dalam konteks kewarisan, KHI merupkan hukum positif yang mengatur berbagai persoalan kewarisan umat Islam Indonesia. Dalam KHI apakah terdapat landasan normatif yang bisa digunakan sebagai solusi perolehan bagian harta peninggalan bagi ahli waris non-Muslim, inilah masalah yang harus didiskusikan secara cermat.

Kerabat non-Muslim dalam kewarisan Islam kedudukannya terhalang oleh perbedaan agama sebagaimana dinyatakan oleh Hadis, dan dikenal dengan istilah mawāni' al-irts. Dengan mempertimbangkan dasar Hadis tersebut, secara dogmatis ada hambatan besar untuk menetapkan kerabat non-Muslim sebagai ahli waris. Namun pada sisi lain, Hukum Islam dihadapkan pada ajakan untuk dapat menyelesaikan problem-problem yang muncul di masyarakat. Karena itu perlu ditemukan terobosan melalui ijtihad agar persoalan yang ada dapat diselesaikan dengan baik tanpa menabrak aturan agama Islam.

Sehubungan dengan ketentuan kewarisan, Buku Kedua KHI tentang Hukum Kewarisan Pasal 171 huruf c menyatakan: (a) Pewaris adalah orang yang pada saat meninggalnya atau yang dinyatakan meninggal berdasarkan putusan Pengadilan beragama Islam, meninggalkan ahli waris dan harta peninggalan, (b) Ahli waris adalah orang yang pada saat meninggal dunia mempunyai hubungan darah atau hubungan perkawinan dengan pewaris, beragama Islam dan tidak terhalang karena hukum untuk menjadi ahli waris.

Pasal KHI di atas menjelaskan bahwa pada saat meninggalnya pewaris, ahli waris nasabiyyah maupun sababiyyah harus beragama Islam. Hal ini berakibat hukum apabila ahli waris tidak beragama Islam maka mereka tidak diposisikan sebagai ahli waris. Sedangkan untuk mengetahui ahli waris beragama Islam, Pasal $172 \mathrm{KHI}$ menyatakan bahwa ahli waris dipandang beragama Islam dapat diketahui dari kartu identitasnya, pengakuan, amalan, atau kesaksian. Sedangkan untuk bayi yang baru lahir atau anak yang belum dewasa, agamanya menurut ayahnya atau lingkungannya.

\footnotetext{
${ }^{46}$ Ahmad Rofiq, Hukum Islam di Indonesia (Jakarta: Raja Grafindo Persada, 2000), h. 24-32.

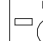

Jurnal Pemikiran Hukum Islam 
Dalam konteks putusan MA disebutkan bahwa dasar pemberian harta peninggalan kepada ahli waris non-Muslim adalah wāṣiyat wājibah. ${ }^{47}$ Apabila dikonfirmasikan dengan Pasal 209 KHI maka terdapat ketidaksesuaian antara dasar hukum yang ada dalam KHI yang mengatur mengenai wāṣiyat wājibah dengan kasus yang diputuskan. Karena aturan Pasal 209 KHI membatasi hanya pada anak dan orangtua angkat yang tidak mendapatkan wasiat, maka bagi mereka dapat menerima wāșiyat wājibah maksimal $1 / 3$ bagian. Sedangkan dalam putusan kasasi dasar wāsiyat wājibah tersebut digunakan untuk memberikan sebagian harta peninggalan bagi ahli waris (anak kandung) yang non-Muslim.

Menurut penulis apa yang diputuskan MA dalam memberikan bagian dari harta peninggalan lebih tepat menggunakan istilah wāṣiyat wājibah, bukan waris. Hal ini dikarenakan pada dua argumentasi. Pertama, dalam sistem pembagian waris Islam, pengaturannya dilakukan secara limitatif dimana pihak-pihak yang bertindak sebagai ahli waris dibatasi pada dua jalur yaitu ahli waris nasabiyyah dan ahli waris sababiyyah saja. Pasal 171 ayat (c) KHI menyatakan yang dimaksud ahli waris adalah orang yang pada saat meninggal dunia mempunyai hubungan darah atau hubungan perkawinan dengan pewaris, beragama Islam dan tidak terhalang karena hukum untuk menjadi ahli waris. Kedua, dalam KHI, wāșiyat wājibah ditetapkan sebagai alternatif pemberian harta peninggalan yang tidak ada pengaturannya dalam farāitid. Menurut Mohammad Daud Ali, ${ }^{48}$ alternatif ini menjadi solusi pemberian harta peninggalan di luar ketentuan farā'ị̣. Alternatif itu misalnya mengenai pembagian waris yang meliputi; pembagian waris dengan perdamaian (Pasal 183), ahli waris pengganti atau plaatsvervulling (Pasal 185), kewarisan kolektif (Pasal 189), hibah dapat diperhitungkan sebagai warisan (Pasal 211), dan wāṣiyat wājibah (Pasal 209). Berkaitan dengan wāsiyat wājibah yang diatur dalam KHI tersebut dapat dikatakan bahwa sebenarnya pengaturan tersebut berhubungan dengan dapat tidaknya pemberian bagian harta peninggalan kepada non ahli waris.

Di sini perlu sikap hati-hati menghindari penggunaan istilah "kewarisan" bagi ahli waris non-Muslim, yang oleh ketentuan farā'ị dianggap sebagai bukan ahli waris. Istilah yang lebih tepat dipakai adalah "harta peninggalan", dan bukan "harta waris". Adapun mengenai wāsiyat wājibah sebagai alternatif pemberian peninggalan kepada non ahli waris didasarkan pada KHI Pasal 209:

\footnotetext{
47Putusan Kasasi MA No. 368 K/AG/1995 tanggal 16 Juli 1998.

48Daud Ali, Hukum Islam.
}

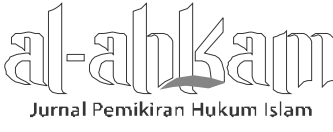


(1) Harta peninggalan anak angkat dibagi berdasarkan Pasal 176 sampai dengan Pasal 193 tersebut di atas, sedangkan terhadap orang tua angkat yang tidak menerima wasiat diberi wāssiyat wājibah sebanyak-banyaknya $1 / 3$ dari harta wasiat anak angkatnya.

(2) Terhadap anak angkat yang tidak menerima wasiat diberi wāṣiyat wājibah sebanyak-banyaknya $1 / 3$ dari harta warisan orang tua angkatnya.

Substansi Buku Kedua KHI tentang Hukum Kewarisan mengatur beberapa inovasi pengaturan waris Islam yang tidak ada ketentuan normatifnya dalam fikih. Karena itu wāṣiyat wājibah bisa digunakan sebagai solusi pemberian harta peninggalan bagi pihak-pihak yang tidak termasuk sebagai ahli waris sababiyyah dan nasabiyyah. Putusan kasasi MA No. 368 K/AG/1995 tanggal 16 Juli 1998 terlihat bahwa hakim-hakim MA melakukan penafsiran ekstensif terhadap makna wāsiyat wājibah sebagaimana ditentukan dalam Pasal $209 \mathrm{KHI}$.

Identifikasi terhadap ada tidaknya penafsiran dalam putusan hakim memang perlu diteliti. Sebab, penegasan alasan mengenai penggunaan metode interpretasi ekstensif dalam peristiwa konkret yang digunakan hakim tidak ditemukan, termasuk dalam putusan hakim. Apalagi pembentuk UU tidak memberikan prioritas kepada salah satu metode dalam menemukan hukum. Hakim menjatuhkan pilihannya berdasarkan pertimbangan metode manakah yang paling meyakinkan dan hasilnya paling memuaskan. Pemilihan metode penafsiran tertentu merupakan otonomi hakim dalam penemuan hukum. Dalam putusan-putusannya hakim tidak pernah menegaskan argumen atau alasan apa yang menentukan untuk memilih metode interpretasi tertentu. ${ }^{49}$

Sebagaimana diketahui penafsiran ekstensif adalah salah satu bentuk penafsiran yang dapat dilakukan oleh hakim karena suatu persoalan yang dihadapi hakim tidak ada aturannya dalam undang-undang. Metode ini memperluas makna kata-kata yang tidak ada dalam undang-undang sehingga suatu peristiwa baru yang tidak terdapat dalam undang-undang dapat dimasukkan ke dalamnya. Sudikno Mertokusumo mengisyaratkan bahwa ketentuan yang tertuang dalam peraturan perundang-undangan tidaklah bernilai mutlak, melainkan tetap terbuka peluang bagi hakim dalam memutuskan perkara yang diajukan kepadanya untuk melakukan langkah-langkah yang tepat dan mencerminkan nilai keadilan. ${ }^{50} \mathrm{Di}$

\footnotetext{
${ }^{49}$ Sudikno, Mengenal Hukum, h. 160.

50Sudikno, Penemuan Hukum, h. 64.

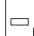

Jurnal Pemikiran Hukum Islam
} 
samping itu, sesuatu yang tidak ada aturannya dalam peraturan perundangundangan bukan berarti sesuatu tersebut dilarang. Dalam hal ini, seorang hakim bisa melakukan rekonstruksi untuk mengisi kekosongan hukum.

Implementasi dari penafsiran ekstensif dalam putusan MA mengenai kewarisan beda agama, bahwa substansi peraturan dalam Pasal 209 KHI tentang wāsiyat wājibah ditetapkan sebagai alternatif untuk memberikan harta waris bagi pihak yang tidak dapat diposisikan sebagai ahli waris, seperti anak dan orangtua angkat. Dalam penafsiran ekstensif makna pihak-pihak non ahli waris diperluas bukan hanya terletak pada anak dan orangtua angkat saja, melainkan juga mencakup pihak-pihak non ahli waris lain seperti kerabat yang berbeda agama atau non-Muslim. Dalam hal ini, penafsiran ekstensif dilakukan karena hakim mempertimbangkan bahwa metode ini yang paling mungkin digunakan untuk menyelesaikan peristiwa konkret yang terjadi di masyarakat.

Dasar pertimbangan penetapan wāșiyat wājibah bagi non-Muslim bisa jadi identik dengan argumentasi yang terjadi di Timur Tengah, dimana para pembaharu hukum memberi kelonggaran dengan menetapkan aturan yang menyatakan bahwa tidak dilarang dalam Hukum Islam apabila seorang Muslim membuat surat-surat wasiat dalam rangka menolong orang-orang yang menganut agama selain Islam yang terhalang untuk bisa mewarisi dari kerabatnya yang Muslim. 51

Keputusan hakim MA tentang pemberian bagian harta peninggalan bagi ahli waris non-Muslim tersebut pada prinsipnya telah menampakkan sebuah keberanian sekaligus kreativitas dalam penegakan hukum di Indonesia. Namun, disadari atau tidak ada putusan tersebut telah menimbulkan semacam kekagetan pada diri umat Islam, karena putusan tersebut berlawanan dengan ketentuan mengenai waris dalam farā'iḍ.

\section{Penemuan Hukum dan Relevansinya bagi Pengembangan Hukum Islam Indonesia}

Sebagaimana telak dipaparkan di depan, produk pemikiran Hukum Islam meliputi; fikih, undang-undang, putusan pengadilan, dan fatwa. Masing-masing dari produk Hukum Islam tersebut memiliki karakteristik yang berbeda satu sama

51J.N.D. Anderson, Islamic Law in Modern World, terj. Machnun Husein (Surabaya: Amarpress, 1991), h. 87-88.

20 Volume 24, Nomor 1, April 2014

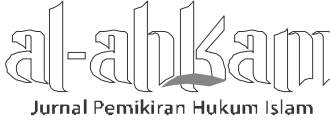


lain. Dari empat produk pemikiran hukum tersebut, menurut Ahmad Rofiq,52 putusan pengadilan dikategorikan sebagai produk pemikiran Hukum Islam yang tingkat dinamikanya tinggi di samping fatwa.

Dengan melihat kedudukannya sebagai salah satu produk pemikiran Hukum Islam, putusan Pengadilan Agama diprediksikan dapat memberikan kontribusi dalam pembaruan Hukum Islam Indonesia. Hal ini dimungkinkan karena putusan yang dijatuhkan pengadilan melibatkan peran hakim yang menjalankan fungsi penegakan hukum. Hakim dalam menjalankan fungsinya dituntut untuk wajib menggali, mengikuti dan memahami nilai-nilai hukum dan rasa keadilan yang hidup dalam masyarakat. Fungsi tersebut merupakan bagian tugas hakim untuk menegakkan kebenaran dan keadilan.

Tugas-tugas yang dilakukan hakim memungkinkan melakukan pembaruan hukum. Adapun tugas dan kewajiban pokok hakim dalam bidang peradilan secara normatif telah diatur dalam UU No. 4 Tahun 2004 antara lain: Mengadili menurut hukum dengan tidak membeda-bedakan orang (Pasal 5 ayat 1), tidak boleh menolak untuk memeriksa dan mengadili suatu perkara yang diajukan dengan dalih bahwa hukum tidak ada atau kurang jelas, melainkan wajib memeriksa dan mengadilinya (Pasal 14 ayat 1), dan hakim wajib menggali, mengikuti dan memahami nilai-nilai hukum dan rasa keadilan yang hidup dalam masyarakat (Pasal 28 ayat 1$)$.

Tugas hakim di atas menuntut kapabilitas hakim bukan hanya pada aspek intelektualnya saja, melainkan juga pada aspek integritas moralnya. Kedua aspek ini akan mendukung tugas-tugas hakim dalam menjalankan tugasnya dalam penegakan hukum. Hakim dituntut untuk mengimplementasikan peraturan perundangundangan, sehingga dalam penanganan perkara-perkara yang didasarkan pada hukum tertulis dapat menjamin adanya kepastian hukum. Selain itu hakim juga wajib mengedepankan nilai-nilai keadilan dalam memutuskan perkara. Dengan demikian, proses penegakan hukum tidak hanya memandang penting terhadap kepastian hukum, tetapi juga mesti menjadikan keadilan hukum sebagai asas yang utama.

Penegasan pentingnya peran hakim dalam penegakan hukum menurut Satjipto Rahardjo berpuncak pada saat hakim menjatuhkan putusan terhadap perkara yang disidangkan di depan pengadilan. Dalam ilmu hukum, bagian terpenting

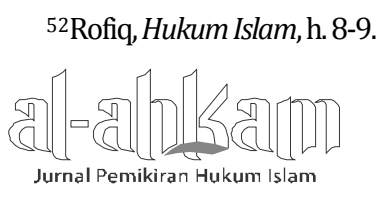


dalam proses mengadili terjadi pada saat memeriksa dan mengadili suatu perkara. Pada hakikatnya apa yang dilakukan hakim adalah memeriksa realita yang terjadi, serta menerapkan hukum yang ada dalam peraturan yang ada. Pada saat diputuskan mengenai bagaimana atau apa hukum yang berlaku untuk suatu persoalan, maka pada waktu itulah penegakan hukum mencapai puncaknya. Menurut Hans Kelsen, sebagaimana dikutip oleh Satjipto Rahardjo, proses penegakan hukum yang dijalankan hakim itu disebut konkretisierung. ${ }^{53}$

Perlunya hakim melakukan penemuan atau penggalian hukum, karena hal tersebut berkaitan dengan fungsi hukum itu sendiri. Dalam kehidupan manusia hukum diharapkan dapat menjalankan fungsinya sebagai social engineering (alat merekayasa masyarakat) dan social control (alat mengontrol masyarakat). ${ }^{54}$ Sebagai alat merekayasa masyarakat (social engineering), hukum diharapkan dapat mengarahkan masyarakat berperilaku sesuai dengan yang dikehendaki hukum. Sedangkan yang dimaksudkan hukum sebagai alat mengontrol masyarakat (social control), berarti hukum harus dapat memastikan perilaku dan atau tatanan kehidupan masyarakat yang sudah tertib harus dapat dipertahankan.

Hukum yang baik adalah hukum yang mampu merespon dinamika perkembangan kehidupan masyarakat. Karena itu, suatu politik hukum mempunyai tugas meneruskan perkembangan hukum dengan jalan membuat ius constituendum (hukum yang dicita-citakan) menjadi ius constitutum (hukum yang berlaku sekarang) atau sebagai penganti ius constitutum yang sudah tidak relevan lagi dengan perkembangan masyarakat. Namun hukum dapat tertinggal dan kehilangan fungsinya apabila hukum tidak memiliki sifat dinamis. Menurut Soerjono Soekanto, ${ }^{55}$ tertinggalnya perkembangan hukum dapat terjadi dalam situasi yang dinamis, yaitu dimana perubahan-perubahan sosial yang tidak diikuti dengan penyesuaian hukum secara paralel terhadap dinamika sosial tersebut.

Dalam kaitan dengan Hukum Islam, keberadaannya juga harus tampil sebagai instrumen peraturan bagi umat Islam yang dinamis. Hukum Islam yang diklaim memiliki watak universal, harus dibuktikan dengan kemampuannya menjawab problem-problem kemanusiaan aktual. Bisa dikatakan hampir semua persoalan

\footnotetext{
53Satjipto Rahardjo, Ilmu Hukum, h. 182-183.

${ }^{54}$ Soerjono Soekanto, Beberapa Permasalahan Hukum dalam Kerangka Pembangunan di Indonesia (Jakarta: Universitas Indonesia Press, 1983), h. 160.

55 Ibid. 
memerlukan solusi dari Hukum Islam, baik pada ranah politik, ekologi, sosial, dan sebagainya. Problem-problem tersebut tidak mungkin dihindari hanya dengan berapologi tidak ada naș-nya atau tidak ada preseden yang dicontohkan generasi awal Islam, melainkan nilai-nilai ajaran Islam itu dapat diimplementasikan untuk ikut berkontribusi dalam pembaruan hukum.

J.N.D. Anderson mengkritik ahli Hukum Islam dalam merespon masalah kontemporer berkecenderungan mengkaji Hukum Islam secara parsial. Metode yang digunakan pada kajian Hukum Islam masih bertumpu pada pendekatan yang ad hoc dan terpisah-pisah dengan menggunakan prinsip takhayyur dan talfiq, sehingga tidak mampu menghasilkan formulasi Hukum Islam yang komprehensif.56 Takhayyur seperti tertuang dalam KHI memang didasarkan pada prinsip mashlahat, namun substansi takhayyur hanya sebatas menyeleksi beberapa pendapat fikih yang dinilai paling tepat, sehingga takhayyur belum sepenuhnya menggambarkan aktivitas ijtihad yang sebenarnya. Meminjam istilah Schacht, pembaruan Hukum Islam kontemporer membutuhkan basis teori yang lebih tegas dan menyeluruh dalam berbagai masalah hukum. ${ }^{57}$ Sementara itu menurut Amir Mu'alim dan Yusdani, hal yang paling mendesak dilakukan ahli Hukum Islam saat ini bagaimana menghasilkan Hukum Islam yang komprehensif dan merumuskan suatu metodologi sistematis yang mempunyai akar yang kokoh. ${ }^{58}$

Sehubungan dengan pembaruan Hukum Islam, Abdul Manan, Hakim Agung MA menyatakan bahwa pembaruan hukum merupakan sesuatu keniscayaan. Ia menegaskan bahwa pembaruan hanya boleh dilakukan dalam bidang hukum yang bersifat zannī al-dalālah. Membentuk hukum baru dalam masalah yang zannī aldalālah ini dilaksanakan dengan cara ijtihad. Karena kompleksnya permasalahan yang dihadapi, ijtihad tidak boleh dilakukan secara parsial. Ijtihad mestinya dilakukan secara komprehensif yang melibatkan para ahli dalam persoalan dan ilmu pengetahuan terkait.59 Karena itu penting dirumuskan metodologi Hukum Islam kontemporer, baik pada aspek ideal moralnya maupun aspek formalnya. Kerangka metodologi pada aspek ideal moral dan formal bertujuan menjaga keabadian nilai-

\footnotetext{
56J.N.D. Anderson, Law Reform in the Moslem World, h. 42.

${ }^{57}$ Josepht Schacht, "Problem of Modern Islamic Legislation", dalam Studia Islamica, Jakarta: Volume 12, 1960, h. 120.

${ }^{58}$ Amir Mu’alim dan Yusdani, Konfigurasi Pemikiran Hukum Islam (Yogyakarta: UII Press, 1999), h. 78.

${ }^{59}$ Abdul Manan, "Globalisasi Membawa Kecenderungan Baru di Bidang Hukum," diadaptasi dari http://www.badilag.net, yang diunduh pada Rabu, 1 Mei 2013.
}

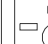

Jurnal Pemikiran Hukum Islam 
nilai ilāhiyyah, kemanusiaan, dan kemaslahatan yang memberikan arah yang benar bagi kehidupan. Tujuan tersebut akan teralisir apabila para ahli Hukum Islam berani meninjau kembali sejarah Hukum Islam untuk menjawab berbagai permasalahan yang timbul. ${ }^{60}$

Dalam upaya mengeliminir pendekatan yang ad hoc, parsial, dan terpisahpisah seperti yang dilakukan oleh para ahli Hukum Islam, lebih jauh Abdul Manan menyatakan perlunya dilaksanakan langkah berikut ini: pertama, mengadakan kajian secara komprehensif terhadap seluruh tradisi Islam, baik bersifat fenomena tradisional maupun Islam modernis dalam berbagai aspek. Kedua, menggunakan kajian ilmiah kontemporer tanpa mengabaikan khazanah intelektual Islam klasik. Ketiga, memasukkan masalah kekinian ke dalam pertimbangan pada saat menginterpretasikan al-Qur'an dan al-Sunnah. Keempat, mengembangkan fikih Islam dengan mengfungsikan ijtihad baik individual maupun kolektif, sehingga menghasilkan materi hukum yang sesuai dengan modernisasi yang sedang berjalan dalam masyarakat Islam. Kelima, menyatukan pendapat antara mazhab-mazhab dalam berbagai masalah hukum yang sama demi kepastian hukum.

Lebih lanjut menurut Abdul Manan metode maslahah adalah metode yang relevan dalam menemukan hukum guna menjawab permasalahan sosial dewasa ini. ${ }^{61}$ Dalam diskursus filsafat Hukum Islam kedudukan maslahah sangat sentral dalam pembentukan Hukum Islam. Mașlaḥah adalah tujuan yang dikehendaki dalam penetapan suatu hukum (maqāṣid al-sharī'ah).62 Pemikiran Abdul Manan itu ingin mengembalikan segala bentuk pembaruan Hukum Islam, termasuk keputusan pengadilan, pada pijakan utamanya yaitu mașlahah. Sehingga ketika seorang mujtahid menetapkan hukum, ia diperkenankan untuk memilih metode paling tepat menurut pertimbangannya, selama keputusan hukum itu berorientasi pada tercapaianya kemaslahatan. Sebagai implikasinya, seorang hakim dalam menetapkan putusan tidak harus terikat dengan ketentuan normatif. Hakim dalam memutus suatu perkara dapat memilih ketentuan yang ada, atau melakukan penemuan hukum. Penemuan hukum dengan salah satu metodenya yaitu penafsiran ekstensif dapat berfungsi mengisi kekosongan hukum.

\footnotetext{
${ }^{60}$ Nur Cahaya, "Hukum Islam Kontemporer: Tantangan dan Pengembangan Metodologi”, dalam kumpulan karangan Syari'at Islam di Indonesia, Fakultas Syari'ah IAIN Sumatera Utara, 2004, h. 320.

${ }^{61}$ Abdul Manan, Aspek-aspek Pengubah Hukum (Jakarta: Prenada Media, 2005), h. 230.

62Fathurrahman, Filsafat, h. 134.
} 
Bentuk-bentuk penafsiran hukum yang terdapat dalam tradisi hukum umum yang terlihat sangat variatif dapat digunakan untuk melengkapi aktivitas dan peluang ijtihad dalam tradisi pemikiran Hukum Islam. Dengan diakomodasinya bentuk-bentuk penafsiran dalam wacana hukum umum, maka terdapat peluang yang luas bagi hakim di lingkungan Peradilan Agama untuk mengkonstruksi Hukum Islam yang lebih aktual dan merefleksikan nilai-nilai keadilan dalam penyelesaian problem-problem kemasyarakatan.

Adanya penemuan hukum dalam masalah pemeliharaan anak dan pemberian wāsilyat wājibah bagi kerabat berbeda agama setelah ditetapkannya KHI, menunjukkan meskipun dua persoalan tersebut sudah ada ketentuannya dalam KHI, namun hal itu tidak menghalangi dilakukannya upaya kreatif dalam mengimplementasikan Hukum Islam. Fenomena ini tentu sangat menggembirakan dan berbeda dengan temuan penelitian penulis pada tahun sekitar 1995 yang menyoal apakah pasca ditetapkannya KHI terdapat ijtihad yang dilakukan hakim PA. Temuan penelitian menunjukkan ternyata selama rentang tahun 1992-1995 tidak terlihat adanya ijtihad dalam bentuk konstruksi hukum pada putusan hakim PA.63 Putusan-putusan yang dikaji dalam penelitian tersebut, menjadi sample yang merepresentasikan kecenderungan umum putusan hakim saat itu akan minimnya kreativitas dan keberanian hakim PA dalam membangun hukum yang bernuansa keadilan.

Meski eksistensi KHI dinilai telah mengisi kekosongan hukum materiil Peradilan Agama di Indonesia dan dianggap sebagai produk Hukum Islam dengan corak keindonesiaan, disadari juga bahwa substansi KHI sebenarnya belum sempurna. ${ }^{64}$ Kenyataan itu menegaskan bahwa pembaruan Hukum Islam memang diperlukan dalam berbagai bentuknya, termasuk salah satunya melalui putusan MA. Pembaruan yang dilakukan MA sudah berlangsung cukup lama. Menurut Abdul Manan, pembaruan Hukum Islam melalui putusan MA telah berlangsung sejak tahun 1974.65

Pembaruan hukum oleh MA memiliki nilai strategis bagi pengembangan Hukum Islam di Indonesia. Ini dikarenakan dalam struktur kenegaraan Indonesia, MA adalah salah satu dari lembaga tinggi negara yang bertanggung-jawab dalam

\footnotetext{
63Budiman, Laporan,

${ }^{64}$ Yahya Harahap, "Informasi Materi KHI" dalam Tim Ditbinbapera, Berbagai Pandangan terhadap Kompilasi Hukum Islam (Jakarta: Depag, 1991), h. 83.

${ }^{65}$ Abdul Manan, Reformasi Hukum Islam di Indonesia (Jakarta: Rajawali Press, 2004) h. 202-203.$$
\square
$$

Jurnal Pemikiran Hukum Islam
} 
penegakan dan pembinaan hukum. MA membawahi badan-badan kekuasaan kehakiman dalam empat (4) lingkungan peradilan, yang meliputi: lingkungan Peradilan Umum (PU), lingkungan Peradilan Agama (PA), lingkungan Peradilan Militer (PM), dan lingkungan Peradilan Tata Usaha Negara (PTUN). Di samping itu dalam sistem peradilan di Indonesia MA merupakan lembaga top judiciary atau kekuasaan lembaga peradilan yang tertinggi. Dalam posisi yang demikian, putusan hukum hakim MA dapat menjadi yurisprudensi bagi hakim lain dalam memutuskan perkara yang sama, terutama di pengadilan pada tingkat di bawahnya.

MA telah melakukan peran pembaruan Hukum Islam, alasannya karena materi Hukum Islam yang terkandung dalam fikih maupun peraturan perundangundangan perlu diaktualisasikan kembali. Pada satu sisi peraturan perundangundangan belum lengkap atau tidak mengaturnya, dan pada sisi lain kebutuhan penyelesaian persoalan tersebut sangat mendesak. Karena itu MA sebagai lembaga peradilan dapat berperan membangun hukum baru yang sesuai dengan perkembangan di masyarakat.66

Putusan MA tentang dua persoalan di depan didasari pada pemahaman kritis terhadap kecenderungan di masyarakat yang dinamis. Kondisi masyarakat Islam yang tengah mengalami proses perubahan, menuntut adanya inovasi hukum. Dalam hubungan ini Hasbi Hasan itu menyatakan, putusan-putusan dalam bidang hukum perdata di Pengadilan Agama harus meniru MA, yang telah mengalami pergeseran dari kerangka Hukum Islam tradisional ke kerangka hukum positif. Pergeseran itu ditandai oleh kuatnya paradigma legalisme pada level penerapan hukum maupun penemuan hukum. Dalam penerapan hukum, direpresentasikan oleh putusan yang mengedepankan ketentuan legal formal. Sedangkan dalam level penemuan hukum, putusan hakim ditandai oleh kecenderungan mempraktekkan pola ijtihad selektif ketimbang ijtihad formalitas dalam penyelesaian perkara yang ditanganinya.67 Sementara itu Ketua PTA Semarang, Chatib Rasyid menyatakan bahwa hakim PA yang dalam memutuskan perkara menggunakan kaidah hukum progresif, pada hakikatnya akan menemukan kaidah hukum itu sendiri.68

Putusan MA memiliki peran strategis, karena putusan MA dapat menentukan corak nilai hukum dan keadilan. Pada perkembangan berikutnya, putusan MA

\footnotetext{
66Ibid., h. 201.

${ }^{67}$ Hasbi Hasan, "Yurisprudensi MA....."

${ }^{68} \mathrm{Ibid}$.
}

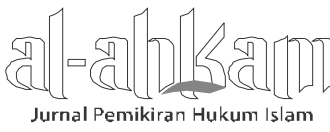


akan menentukan wajah hukum di Indonesia, serta mempengaruhi pergeseran pemikiran hukum yang bertujuan mencapai keadilan. Hakim pengadilan diwajibkan selalu menggali, mengikuti dan memahami nilai hukum yang hidup di masyarakat.69 Berikutnya nilai hukum tersebut dapat dijadikan kaidah hukum dalam menegakkan keadilan. Dalam perannya tersebut MA telah menjalankan fungsinya membentuk hukum atau dikenal dengan istilah judge made law. ${ }^{70}$

Secara lebih umum ijtihad dan penemuan hukum dalam legislasi Indonesia kontemporer erat kaitannya dengan pengembangan budaya Hukum Islam. Dalam hal ini umat Islam dihadapkan dua kemungkinan, yaitu hukum positif Islam yang terbatas pada permasalahan hukum yang berlaku bagi kaum muslimin saja, ataukah nilai-nilai Hukum Islam yang dapat diterapkan bagi seluruh warga negara. Kedua alternatif tersebut akan mempengaruhi pembentukan hukum nasional pada masa yang akan datang.

\section{Kesimpulan}

Sistem hukum Indonesia yang memiliki kecenderungan menerapkan sistem Eropa Continental dan Anglo Saxon berdampak pada munculnya putusan pengadilan contra legem, putusan yang menyimpang dari peraturan. Implikasi konkretnya terlihat dalam penyelesaian sengketa pengasuhan anak dan pemberian harta peninggalan kepada ahli waris non-Muslim. Putusan MA menentukan keimanan seorang ibu menjadi parameter menentukan hak asuh anak yang berbeda dengan Pasal 105 KHI. Sementara pemberian harta peninggalan pada ahli waris nonMuslim dibangun berdasar penafsiran memperluas cakupan pihak dalam wāṣiyat wājibah.

Dalam putusan MA di atas, ada kesan sikap hakim MA yang bertolak belakang apabila dilihat dari perspektif pemikiran Hukum Islam. Pada satu sisi putusan MA mengesankan adanya sikap konservatisme hukum, yang terlihat dalam putusan hakim MA No. 349K/AG/2006. Namun pada putusan yang lain, hakim MA memperlihatkan keberaniannya, bahkan mengesankan kuatnya pemikiran liberal dalam putusan hukumnya. Hal ini tercermin dalam putusan kasasi MA No. 368 K/AG/1995 yang mengadili bagian harta penginggalan bagi ahli waris beda agama.

\footnotetext{
${ }^{69}$ Abdurrahman, "Kewajiban Hakim untuk Menggali Nilai Hukum yang Hidup dalam Masyarakat", dalam Suara Uldilag, Nomor 3 (Jakarta: Mahkamah Agung, 2003), h. 62-63.

${ }^{70}$ Lie Oen Hock, "Yurisprudensi sebagai Sumber Hukum", dalam Din Muhammad (ed.), Pustaka Peradilan, Jilid VIII (Jakarta: Mahkamah Agung, 1995), h. 20.
}

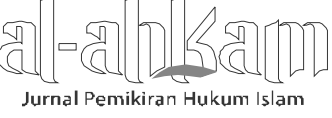


Penemuan hakim MA berkontribusi secara positif bagi pengembangan Hukum Perdata Islam Indonesia. Putusan MA memiliki nilai yang strategis karena akan memberikan warna bagi penegakan hukum di Indonesia. Putusan-putusan tersebut pada prakteknya kemudian dijadikan yurispudensi oleh hakim di lingkungan Peradilan Agama. [a]

\section{DAFTAR PUSTAKA}

Aaron, Thomas, The Control of Police Discretions, Springfield: Charles D. Thomas, 1960.

Anderson, J.N.D., Law Reform in the Moslem World, London: University of London, 1976.

Anderson, J.N.D., Islamic Law in Modern World terj. Machnun Husein, Surabaya: Amarpress, 1991.

Budiman, Achmad Arief, "Ijtihad Hakim Pengadilan Agama Pasca Kompilasi Hukum Islam”, Laporan Penelitian Puslit IAIN Walisongo Semarang, tidak diterbitkan, 2005.

Cahaya, Nur, "Hukum Islam Kontemporer: Tantangan dan Pengembangan Metodologi", dalam Kumpulan karangan Syari'at Islam di Indonesia, Medan: Fakultas Syari'ah IAIN Sumatera Utara, 2004.

Coulson, Noel J., Conflict and Tension in Islamic Jurisprudence, Chiccago: The University of Chicago Press, 1969.

Din Muhammad (ed.), Pustaka Peradilan, Jilid VIII, Jakarta: Mahkamah Agung, 1995.

Djamil, Fathurrahman, Filsafat Hukum Islam, Jakarta: Logos Wacana Ilmu, 1997.

Fakam, M., Penjaringan Perkara Pidana oleh Polisi: Penemuan hukum Kepolisian, Jakarta: Pradnya Paramita, 1991.

Friedman, Lawrence M., American Law, New York: W.W. Norton \& Company, 1984.

Gunawan, Ahmad, dan Mu'ammar Ramadhan (eds), Menggagas Hukum Progresif Indonesia, Yogyakarta: Pustaka Pelajar-IAIN Walisongo-PDIH UNDIP, 2006.

Hasan, Hasbi, "Yurisprudensi Mahkamah Agung dan Prospeknya dalam Pengembangan Hukum Perdata Islam Indonesia," Semarang, dalam Seminar Nasional, 5 April 2011.

28 Volume 24, Nomor 1, April 2014

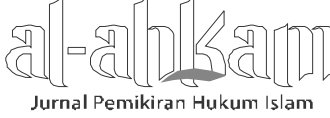


Jurnal Studia Islamica, Jakarta: Volume 12 Tahun 1960.

Jamil, Fathurrahman, Filsafat Hukum Islam, Jakarta: Logos, 1997.

Kamil, Ahmad dan M. Fauzan, Kaidah-kaidah Hukum Yurisprudensi, Jakarta: Prenada Media, 2005.

Mahkamah Agung, Kapita Selekta Hukum Perdata Agama dan Penerapannya, Jakarta: MA, 2004.

Manan, Abdul, Reformasi Hukum Islam di Indonesia, Jakarta: Rajawali Press, 2004.

Manan, Abdul, Aspek-aspek Pengubah Hukum, Jakarta: Prenada Media, 2005.

Mertokusumo, Sudikno, Penemuan Hukum, Yogyakarta: Liberty, 1996.

Mertokusumo, Sudikno, Mengenal Hukum, Yogyakarta: Liberty, 1999.

Madhkūr, Muhạmmad Salām, al-Qaḍ̄à' fi al-Islām, terj. Imron A.M., Peradilan dalam Islam, Surabaya: Bina Ilmu, 1990.

Mu'alim, Amir dan Yusdani, Konfigurasi Pemikiran Hukum Islam, Yogya: UII Press, 1999.

Muslehuddin, Muhammad, Filsafat Hukum Islam dan Pemikiran Orientalis: Studi Perbandingan Sistem Hukum Islam, Yogyakarta: Tiara Wacana, t.th.

Putusan Kasasi Mahkamah Agung RI No. 368K/AG/1995.

Putusan Kasasi Mahkamah Agung RI No.349K/AG/2006

Rahman, Fazlur, Islam and Modernity, terj. Ahsin Mohammad, Islam dan Modernitas: tentang Transformasi Intelektual, Bandung: Penerbit Pustaka, 1995.

Rofiq, Ahmad, Hukum Islam di Indonesia, Jakarta: PT. Raja Grafindo Persada, 2000.

Rahardjo, Satjipto, Hukum, Masyarakat dan Pembangunan, Bandung: Alumni, 1980.

Rahardjo, Satjipto, Ilmu Hukum, Bandung: Citra Aditya Bhakti, 1996.

Rahardjo, Satjipto, Sisi-Sisi Lain dari Hukum di Indonesia, Jakarta: Kompas, 2006.

Rasjidi, Lili dan Ira Rasjidi, Dasar-dasar Filsafat dan Teori Hukum, Bandung: Alumni, 2001.

al-Shātịī, al-Muwāfaqāt fi Ușūl al-Aḥkām, Jilid II, Beirut: Dār al-Fikr, t.th.

Suara Uldilag No. 3, Jakarta: Mahkamah Agung, 2003.

Syarifuddin, Amir, Hukum Perkawinan Islam di Indonesia: Antara Fikih Munakahat dan Undang-undang Perkawinan, Jakarta: Prenada Media, 2006.

Salman, Otje dan Anton F. Susanto, Teori Hukum, Mengingat, Mengumpulkan dan Membuka Kembali, Bandung: Refika Aditama, 2005.

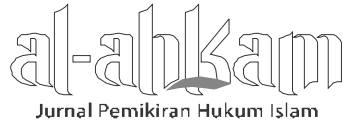


Achmad Arief Budiman

Soekanto, Soerjono, Beberapa Permasalahan Hukum dalam Kerangka Pembangunan di Indonesia, Jakarta: Universitas Indonesia Press, 1983.

Soekanto, Soerjono, Kegunaan Sosiologi Hukum Bagi Kalangan Hukum, Bandung: Citra Aditya Bakti, 1991.

Tim Ditbinbapera, Berbagai Pandangan terhadap Kompilasi Hukum Islam, Jakarta: Depag, 1991.

Zahrah, Muḥammad Abū, Ușūl al-Fiqh, Mesir: Dār al-Fikr al-'Arabī, t.th.

Zein, Satria Effendi M., Problematika Hukum Keluarga Islam Kontemporer: Analisis Yurisprudensi dengan Pendekatan Ushuliyah, Jakarta: UIN Jakarta dan Balitbang Depag RI, 2005.

Internet:

http://www.badilag.net/index.php situs resmi Badan Peradilan Agama Mahkamah Agung Republik Indonesia, data diunduh tanggal 5 Pebruari 2012.

http://www.jurnalhukum. com/penafsiran-hukum-interpretasi-hukum/ diunduh pada hari Rabu, 22 Mei 2013.

Liza Erwina, "Penemuan Hukum oleh Hakim (Rechtvinding)", Fakultas Hukum Jurusan Hukum Pidana USU, diadaptasi dari www.slideshare.net diunduh pada Jum'at, 13 Setember 2013.

Manan, Abdul, "Globalisasi Membawa Kecenderungan Baru di Bidang Hukum," diadaptasi dari http://www.badilag.net, yang diunduh pada Rabu, 1 Mei 2013.

Sugiri Permana, "Paradigma Baru dalam Penyelesaian Sengketa Hak Asuh Anak Pada Peradilan Agama” dalam http://badilag.mahkamahagung.go.id/ artikel/1302.html data diunduh pada Minggu, 9 Juni 2013.

Sugiri Permana, "Paradigma Baru dalam Penyelesaian Sengketa Hak Asuh Anak pada Peradilan Agama" diunduh dari www.badilag.net/data/ARTIKEL/ varia.pdf, Jum'at, 13 September 2013.

30 Volume 24, Nomor 1, April 2014

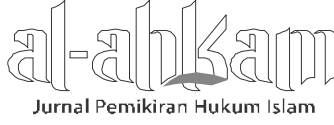

